第 22 群

\section{4 慢性炎患者の血中ケイ素量について}

武藤二郎○島田孝之, 小會寿夫, 中山杜人，依田勝 金子 裕（群大）

目的: 慢性炎症の原因的要素としてケイ菨が大きな役 割を果している事吕，疫学，組織学，実験から明かにさ れたが(MUTO, et al, 1970，1973，1974)，その役割を 具体的にするための一つとして血中ケイ索を検討した。

\section{5 環境亡耳鼻㸶喉科疾患（続報：メキシコ・マ ヤ族後裔の調查より)}

高橋 良，○吉見充德，浜田雅之，森山 寛(慈大)

私共仙以前より環境が睤副鼻腔炎の発症と関連のある 事を認めているので，これ沉いての各国各地の調查成 績について報告してきたが，今回は紀元前後から数世紀

\section{6 大気污染地区における学童結膜のロホウ㨾隆 起と上気道リンパ組織について}

○高山乙彦，押尾良功，鈴木隆夫，望月一男(日大)

目的: 大気污染地区飞扔ける学童の結膜ロホー样隆起 の発生と上気道淋巴組織の刺激症状発生との関係を知ろ ろとした。

方法: アンケート，臨床検查及び病理組織学的検查飞

\section{7 環境騒音の純音聴力に対する影響調查成績}

○岡田 諒（東邦大）野村恭也（東大）杉山茂夫 (阪大) 関 和夫（慈大）

交通騒音，都市騷音など，いわゆる環境蜸音がその地域 の人達に大きな心理的影響を与兄ていることは否定でき ない事実であるが，炖音聴力対する影隌については確 たる調查報告㹥稀である。私どもは過去 4 年間炕わたっ
方法：慢性炎とアレルギ一疾患とは，疫学その他の点で 相反した傾向を示す。そこで慢性中耳炎を中心とした慢 性炎患者と定型的な夓アレルギ一患者の血中ケイ素濃度 を測定比校した。結果：血中ケイ菜量は，3 10ppm(湿 重量), 15 50ppm (乾重量)であるが, その簛围の中 で僈性炎患者は鼻アレルギーに較へて高い值を示した。

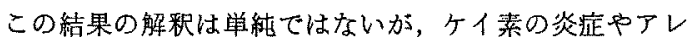
ルギーに対するかかかり方を考克る上に一つの重要な手 脚りを与兄る。

にわたって独特の高度な文化をるっていた事で知られて いるメキシコ・マヤ埃の末感について調查したので報告 する。即ち彼等活ユカタン半島の密林の中にマヤ族の純 系として現在まで住居しているが，彼等の現在の生活環 境は昔時のマヤ族をしのふ影むなく，原始生活に近い生 活を営んでいるが，私共の予想と異った成果を得たので これを以前汇調查した他国の調查成績と比較検討したの で報告する次第である。

よった。アンケートは耳鼻咽焐科的，眼科的に夫々 2 項 目飞ついて行った。臨床検查は耳鼻咽喉科的飞は, 咽頭 後壁淋巴口ホー增生と, 咽頭側索堙脹とをチェックした。 眼科的に㹥口ホー梯隆起が認められたロホー性結膜炎を チェックした。

結果：アンケートと臨床検查の結果加 5 , 症例は少数 であったが，咽頭後壁琳巴ロホーと，結膜ロホー样隆起 とは，関係があるよう炕思われた。

て，各地の環境騷音のある地域，肪よびこれと対照比較 する意味で環境騷音というべき音響条件の考えられない 地域の人達记ついて純音㥁力梌查, 高周波带域の聴力レ ベルの検査を行ってきたので，これらを比較検討し報告 する。検沓対象地域は，東京羽田地区，江戸川地区，大 阪伊丹地区, 岩手県宮古地方三地区, 山形県寒河江地区 で,オージオメータはリオン AA34E (ISO), 受話器は TDH39を使用した。

第 23 群

78 减衰振子様回転検査後に誘器された自発眼振 について

○本村美雄, 坂本 裕, 松川純一, 小津雷助( 川崎 市立病院）

娍意振子様回転検查（略DPRT）終了直後任自発眼振 柃查を行うとそれまで目発眼振の認められなかった症
例で，自発眼振を認める粎炕なったり，また自発眼振を 認めていた症例では，その性啠㵝化が見られることが しばしばある。

今回は, この DPRT 直後の自発眼振と暗所開眼時の 自発眼振との関係, その他の平衡機能検查所見との比 較，臨床的な意楸などについて梌討を行った。 